\title{
HUBUNGAN BAYI BERAT LAHIR RENDAH (BBLR) DENGAN KEJADIAN ASFIKSIA NEONATORUM DI RUMAH SAKIT Dr. H. ABDUL MOELOEK BANDAR LAMPUNG
}

\author{
Mardheni Wulandari', Baruddin Hassim², Fima Iqlima ${ }^{3}$ \\ 'Dosen Fakultas Kedokteran Universitas Malahayati Bandar Lampung \\ Email: mardheniw@gmail.com \\ 2Dosen Fakultas Kedokteran Universitas Malahayati Bandar Lampung \\ Email: hassim_b@gmail.com \\ 3Mahasiswa Fakultas Kedokteran Universitas Malahayati Bandar Lampung \\ Email: fiimaiqqlima@gmail.com
}

\begin{abstract}
Background: Low birth weight babies are the babies with birth weight $<2500$ grams. Low birth weight babies have many problems in the body due to the body organs that have not developed perfectly, so that in these low birth weight babies can lead to asphyxia neonatorum. Asphyxia neonatorum is a state of respiratory failure that occurs spontaneously and regularly soon after birth.

Objective: To determine the correlation between Low birth weight infant and the occurance of asphyxia neonatorum in Dr. H. Abdoel Moeloek hospital Bandar Lampung 2016

Method: This research uses analytic non experiment with cross sectional approach. The population of this research was the entire low birth weight babies that were nursed in Dr. H. Abdoel Moeloek Bandar Lampung 2016. The sampling technique was chosen by using purposive sampling technique. Determination of sample size in this research used slovin formula, it was obtained of 197 samples. The data were analyzed with chi sequare test.

Result: BBLR babies with asphyxia are 97 respondents $(62,2 \%), B B L R$ babies with no asphyxia are 26 respondents $(18,1 \%)$. Non- BBLR (Dismatur) babies with asphyxia are 59 respondents $(37,8 \%)$, non- BBLR (Dismatur) babies with no asphyxia are 118 respondents (81,9\%). Factors can BBLR with hight frecuency is maternal factor is premature rupture of membranes are 155 respondents $(51,7 \%)$, and low frequency is hidramnion are 20 respondents (6,7\%). Staistic test result chi sequare is obtained $p$ value $0,000(p<0,05)$ which means there is a correlation between low birth weight babies and theoccuranceof asphyxia neonatorum.

Conclusion: There is a correlation between low birth weight babies and the occurance of asphyxia neonatorum. With $p$ value $=0,000(\mathrm{Cl}=95 \%) . O R$ value $=7,526$ which means low birth weight babies have 8 times risky suffering from asphyxia neonatorum compared to the sufficient birth weight babies.

Sugesstion It is expected that this research can be used as information about the relationship of low birth weight babies with the incidence of asphyxia neonatorum and in order to reduce the risk factors for $L B W$.
\end{abstract}

Keywords: Low Birth Weight Babies, Asphyxia Neonatorum

\section{ABSTRAK}

Latar belakang : Bayi berat lahir rendah adalah bayi dengan berat lahir <2500 gram. Bayi berat lahir rendah banyak mengalami permasalahan dalam tubuhnya dikarenakan organ tubuh yang belum berkembang secara sempurna, sehingga pada bayi berat lahir rendah ini dapat menyebabkan terjadinya asfiksia neonatorum. Asfiksia neonatorum adalah keadaan bayi gagal nafas yang terjadi secara spontan dan teratur segera setelah lahir.

Tujuan penelitian: Mengetahui hubungan bayi berat lahir rendah dengan kejadian asfiksia neonatorum di Rumah Sakit Dr. H. Abdul Moeloek Bandar Lampung tahun 2016.

Metode Penelitian: Penelitian ini menggunakan metode analytic komparatif dengan pendekatan cross sectional. Populasi dalam penelitian ini adalah seluruh bayi berat lahir rendah yang dirawat di rumah sakit $\mathrm{Dr}$. $\mathrm{H}$. Abdul Moeloek Bandar Lampung tahun 2016. Sampel dipilih menggunakan teknik purposive sampling. Penentuan besar sampel dalam penelitian ini menggunakan rumus slovin didapatkan sampel sebanyak 197 sampel. Data dianalisis dengan uji chi square. 
Hasil : Bayi BBLR yang mengalami asfiksia sebanyak 97 responden (62,2\%), bayi BBLR yang tidak mengalami asfiksia sebanyak 26 responden (18,1\%). Bayi tidak BBLR (Dismatur) yang mengalami asfiksia sebanyak 59 responden $(37,8 \%$ ), bayi tidak BBLR (Dismatur) yang tidak mengalami asfiksia sebanyak 118 responden $(81,9 \%)$. Faktor- faktor yang menyebabkan bayi berat lahir rendah dengan frekuensi tertinggi dari faktor ibu yaitu ketuban pecah dini sebanyak 155 responden $(51,7 \%)$, dan frekuensi terendah dari faktor janin yaitu hidramnion sebanyak 20 responden $(6,7 \%)$. Hasil uji statistik chi square didapat nilai $P$ value 0,000 $(P<0,05)$ yang artinya terdapat hubungan bayi berat lahir rendah dengan kejadian asfiksia neonatorum.

Kesimpulan: Terdapat hubungan bayi berat lahir rendah dengan kejadian asfiksia neonatorum dengan $P$ value $=0,000(\mathrm{Cl}=95 \%)$. Nilai OR sebesar 7,526 yang artinya bayi berat lahir rendah memiliki risiko 8 kali terjadinya asfiksia neonatorum dibanding bayi berat lahir cukup.

Saran Bagi masyarakat diharapkan dari penelitian ini dapat dijadikan informasi mengenai hubungan bayi berat lahir rendah dengan kejadian asfiksia neonatorum dan agar dapat mengurangi faktor risiko terjadinya BBLR.

Kata Kunci : Bayi berat lahir rendah, Asfiksia neonatorum.

\section{PENDAHULUAN}

Saat dilahirkan biasanya bayi aktif dan segera sesudah tali pusat dijepit bayi menangis, keadaan ini dapat merangsang pernafasaan. Akan tetapi beberapa bayi mengalami depresi saat dilahirkan dengan gejala tonus otot yang menurun dan mengalami kesulian dalam mempertahankan pernafasan. Kondisi ini dapat menyebabkan kurangnya pengambilan oksigen dan pengeluaran karbondioksida (Prawirohardjo,2009). Asfiksia neonatorum adalah keadaan bayi baru lahir yang gagal bernapas secara spontan dan teratur segera setelah lahir. Keadaan asfiksia neonatorum ini disertai dengan adanya hipoksia, hiperkapnia dan berakhir dengan asidosis. Hipoksia yang terjadi pada asfiksia ini merupakan hal penting yang dapat menghambat kemampuan bayi untuk dapat menjalani kehidupan ekstrauterin (Abdoerrachman dkk,1985).

Menurut laporan dari World Health Organization (WHO), setiap tahunnya terdapat sekitar 3\% (3.6 juta) dari 120 juta bayi mengalami asfiksia, hampir 1 juta bayi yang mengalami asfiksia ini meninggal dunia (Herawati,2013). Di Indonesia angka kejadian asfiksia lebih kurang 4 dari tiap 1000 kelahiran hidup, secara keseluruhan 110.000 neonatus meninggal setiap tahun karena asfiksia, di pedesaan asfiksia menyebabkan kematian antara 30-56\% (Dewi dkk,2005). Sedangkan di provinsi lampung, pada tahun 2014 terdapat 277 bayi yang mengalami asfiksia (Dinkes, 2014).

Bayi Berat Lahir Rendah (BBLR) adalah bayi dengan berat lahir $<2500$ gram tanpa memandang masa gestasi. BBLR dapat terjadi pada bayi kurang bulan ( $<37$ minggu) atau pada bayi cukup bulan (37-42 minggu). Data diseluruh dunia bahwa $15,5 \%$ bayi mengalami BBLR. $90 \%$ BBLR terjadi dinegara berkembang (Suyoko dkk,
2010). Di Indonesia, presentase tertinggi yang mengalami BBLR terdapat di Provinsi Sulawesi Tengah (16.8\%) (Kemenkes RI, 2014). Menurut data Dinas Kesehatan Kota Bandar Lampung tahun 2014, terdapat 1.1\% kasus yang mengalami BBLR. Angka ini sedikit berbeda bila dibandingkan kasus BBLR pada tahun 2013 yaitu sebanyak 1\% (Dinkes, 2014).

Banyak faktor yang dapat menyebabkan asfiksia neonatorum, salah satunya adalah Bayi Berat Lahir Rendah (BBLR). Berdasarkan penelitian pada tahun 2015 yang telah dilakukan oleh Saputro, di Surakarta yang berjudul Hubungan Antara Berat Badan Lahir Rendah Dengan Asfiksia Neonatorum menjelaskan bahwa terdapat hubungan antara BBLR dengan asfiksia (Saputro, 2015),dan penelitian yang telah dilakukan oleh Fajarwati pada tahun 2016 di Semarang yang berjudul Hubungan Antara Berat Badan Lahir Dan Asfiksia Neonatorum menjelaskan bahwa tidak terdapat hubungan yang bermakna antara berat badan lahir dengan kejadian asfiksia (Fajarwati dkk, 2016).

\section{METODOLOGI PENELITIAN}

Penelitian ini menggunakan metode analytic komparatif dengan pendekatan cross sectional. Populasi seluruh bayi berat lahir rendah yang dirawat di rumah sakit Dr. H. Abdul Moeloek Bandar Lampung tahun 2016. Sampel dipilih menggunakan teknik purposive sampling. Penentuan besar sampel dalam penelitian ini menggunakan rumus slovin didapatkan sampel sebanyak 197 sampel. Data dianalisis dengan uji chi square.

\section{HASIL DAN PEMBAHASAN \\ Distribusi Frekuensi Bayi Berat Lahir Rendah}

Distribusi frekuensi Bayi Berat Lahir 
Rendah (BBLR) di Rumah Sakit Dr. H. Abdul Moeloek Bandar Lampung Tahun 2016 adalah sebagai berikut:

Tabel 1.

Distribusi Frekuensi Bayi Berat Lahir Rendah (BBLR)

\begin{tabular}{lcc}
\hline \multicolumn{1}{c}{ BBLR } & Frekuensi & Presentase (\%) \\
\hline BBLR & 123 & 41,0 \\
Bukan BBLR (Dismatur) & 177 & 59,0 \\
\hline \multicolumn{1}{c}{ Jumlah } & 300 & 100 \\
\hline
\end{tabular}

Berdasarkan tabel 1 diketahui bahwa kejadian Bayi Berat Lahir Rendah di Rumah Sakit Dr. H. Abdul Moeloek Bandar Lampung Tahun 2016 sebanyak 123 responden $(41,0 \%)$, bukan BBLR (Dismatur) sebanyak 177 responden (59,0\%).

\section{Distribusi Frekuensi Asfiksia Neonatorum}

Distribusi frekuensi Asfiksia Neonatorum di Rumah Sakit Dr. H. Abdul Moeloek Bandar Lampung Tahun 2016 adalah sebagai berikut:

Tabel 2.

\section{Distribusi Frekuensi Asfiksia Neonatorum}

\begin{tabular}{lcc}
\hline Asfiksia Neonatorum & Frekuensi & Presentase (\%) \\
\hline Asfiksia Berat & 39 & 13,0 \\
Asfiksia Sedang & 141 & 47,0 \\
Tidak Asfiksia & 120 & 40,0 \\
\hline \multicolumn{1}{c}{ Jumlah } & 300 & 100 \\
\hline
\end{tabular}

Berdasarkan tabel 2 diketahui bahwa kejadian Asfiksia Neonatorum di Rumah Sakit Dr. H. Abdul Moeloek Bandar Lampung Tahun 2016 sebanyak 39 responden yang mengalami Asfiksia Berat $(13,0 \%)$, sebanyak 141 responden yang mengalami asfiksia sedang (47,0\%), sebanyak 120 responden yang tidak mengalami asfiksia $(40,0 \%)$.

\section{Distribusi Frekuensi faktor ibu}

Distribusi frekuensi faktor ibu yang menyebabkan bayi berat lahir rendah (BBLR) di Rumah Sakit Dr. H. Abdul Moeloek Bandar Lampung Tahun 2016 adalah sebagai berikut:

Tabel 3.

Ketuban Pecah Dini

\begin{tabular}{lcc}
\hline & $\begin{array}{c}\text { Ketuban pecah } \\
\text { Dini }\end{array}$ & $\begin{array}{c}\text { Presentase } \\
(\%)\end{array}$ \\
\hline Ya & 155 & 51,7 \\
Tidak Ada Kelainan & 145 & 48,3 \\
\hline \multicolumn{1}{c}{ Jumlah } & 300 & 100 \\
\hline
\end{tabular}

Berdasarkan tabel 3 diketahui bahwa faktor ibu yang menyebabkan bayi berat lahir rendah (BBLR) yaitu ketuban pecah dini di Rumah Sakit Dr. H. Abdul Moeloek Bandar Lampung Tahun 2016 sebanyak 155 responden $(51,7 \%)$, responden yang tidak ada kelainan sebanyak 145 responden $(48,3 \%)$.

Tabel 4.

Solusio Plasenta

\begin{tabular}{lcc}
\hline & Solusio plasenta & Presentase (\%) \\
\hline Ya & 72 & 24,0 \\
Tidak Ada Kelainan & 228 & 76,0 \\
\hline Jumlah & 300 & 100 \\
\hline
\end{tabular}

Berdasarkan tabel 4 diketahui bahwa faktor ibu yang menyebabkan bayi berat lahir rendah (BBLR) yaitu solusio plasenta di Rumah Sakit Dr. H. Abdul Moeloek Bandar Lampung Tahun 2016 sebanyak 72 responden $(24,0 \%)$, responden yang tidak ada kelainan sebanyak 228 responden $(76,0 \%)$.

Tabel 5.

Plasenta Previa

\begin{tabular}{lcc}
\hline & Plasenta previa & Presentase (\%) \\
\hline Ya & 46 & 15,3 \\
Tidak Ada Kelainan & 254 & 84,7 \\
\hline \multicolumn{1}{c}{ Jumlah } & 300 & 100 \\
\hline
\end{tabular}

Berdasarkan tabel 5 diketahui bahwa faktor ibu yang menyebabkan bayi berat lahir rendah (BBLR)yaitu plasenta previa di Rumah Sakit Dr. H. Abdul Moeloek Bandar Lampung Tahun 2016 sebanyak 46 responden (15,3\%), responden yang tidak ada kelainan sebanyak 254 responden $(84,7 \%)$.

Tabel 6.

Eklampsi, Preeklampsi, Preeklampsi Berat

\begin{tabular}{lcc}
\hline \multicolumn{1}{c}{ Faktor ibu } & $\mathrm{N}$ & Presentase (\%) \\
\hline Eklampsi & 96 & 32,0 \\
Preeklampsi & 53 & 17,7 \\
Preeklampsi berat & 37 & 12,3 \\
\hline Tidak ada kelainan & 114 & 38,0 \\
\hline \multicolumn{1}{c}{ Jumlah } & 300 & 100 \\
\hline
\end{tabular}

Berdasarkan table 6 diketahui bahwa faktor ibu yang menyebabkan bayi berat lahir rendah (BBLR) di Rumah Sakit Dr. H. Abdul Moeloek Bandar Lampung Tahun 2016 yang tertinggi pada kategori ibu yang tidak memiliki 
kelainan, sebanyak 114 responden $(38,0 \%)$.dan terendah ibu yang mengalami pre-eklampsia berat. yang mengalami eklampsi sebanyak 37 responden $(12,3 \%)$.

\section{Distribusi frekuensi faktor Janin}

Distribusi frekuensi faktor janin yang menyebabkan bayi berat lahir rendah (BBLR)di Rumah Sakit Dr. H. Abdul Moeloek Bandar Lampung Tahun 2016 adalah sebagai berikut:

Tabel 7.

Prematur, Dismatur

\begin{tabular}{lcc}
\hline \multicolumn{1}{c}{ Faktor janin } & $\mathrm{N}$ & Presentase (\%) \\
\hline Prematur & 123 & 41,0 \\
Dismatur & 177 & 59,0 \\
\hline \multicolumn{1}{c}{ Jumlah } & 300 & 100 \\
\hline
\end{tabular}

Berdasarkan tabel 7 diketahui bahwa faktor janin yang menyebabkan bayi berat lahir rendah di Rumah Sakit Dr. H. Abdul Moeloek Bandar Lampung Tahun 2016 sebanyak 123 responden $(41,0 \%)$ yang prematur, sebanyak 177 responden $(59,0 \%)$ yang dismatur.

Tabel 8.

Hidramnion

\begin{tabular}{lcc}
\hline & Hidramnion & Presentase $(\%)$ \\
\hline Ya & 20 & 6,7 \\
Tidak Ada Kelainan & 280 & 93,3 \\
\hline Jumlah & 300 & 100 \\
\hline
\end{tabular}

Berdasarkan tabel 8 diketahui bahwa faktor janin yang menyebabkan bayi berat lahir rendah(BBLR) di Rumah Sakit Dr. H. Abdul Moeloek Bandar Lampung Tahun 2016 sebanyak 20 responden $(6,7 \%)$ yang mengalami hidramnion, yang tidak ada kelainan sebanyak 280 responden $(93,3 \%)$.

Tabel 9.

Kehamilan Ganda

\begin{tabular}{lcc}
\hline & Kehamilan ganda & Presentase (\%) \\
\hline Ya & 24 & 8,0 \\
Tidak Ada Kelainan & 276 & 92,0 \\
\hline \multicolumn{1}{c}{ Jumlah } & 300 & 100 \\
\hline
\end{tabular}

Berdasarkan tabel 9 diketahui bahwa faktor janin yang menyebabkan bayi berat lahir rendah (BBLR) di Rumah Sakit Dr. H. Abdul Moeloek Bandar Lampung Tahun 2016 sebanyak 24 responden $(8,0 \%)$ yang mengalami kehamilan ganda, yang tidak ada kelainan sebanyak 276 responden $(92,0 \%)$.

\section{Distribusi frekuensi faktor persalinan}

Distribusi frekuensi faktor persalinan yang menyebabkan bayi berat lahir rendah(BBLR) di Rumah Sakit Dr. H. Abdul Moeloek Bandar Lampung Tahun 2016 adalah sebagai berikut:

Tabel 10.

Oligohidramnion

\begin{tabular}{lcc}
\hline & Oligohidramnion & Presentase (\%) \\
\hline Ya & 102 & 34,0 \\
Tidak Ada Kelainan & 198 & 66,0 \\
\hline \multicolumn{1}{c}{ Jumlah } & 300 & 100 \\
\hline
\end{tabular}

Berdasarkan table 10 diketahui bahwa faktor persalinan yang menyebabkan bayi berat lahir rendah (BBLR) di Rumah Sakit Dr. H. Abdul Moeloek Bandar Lampung Tahun 2016 sebanyak 102 responden $(34,0 \%)$ yang mengalami oligohidramnion, yang tidak ada kelainan sebanyak 198 responden $(66,0 \%)$.

Tabel 11.

\section{Lilitan Tali Pusat}

\begin{tabular}{lcc}
\hline & Lilitan tali pusat & Presentase (\%) \\
\hline Ya & 94 & 31,3 \\
Tidak Ada Kelainan & 206 & 68,7 \\
\hline \multicolumn{1}{c}{ Jumlah } & 300 & 100 \\
\hline
\end{tabular}

Berdasarkan tabel 11 diketahui bahwa faktor persalinan yang menyebabkan bayi berat lahir rendah (BBLR) di Rumah Sakit Dr. H. Abdul Moeloek Bandar Lampung Tahun 2016 sebanyak 94 responden $(31,3 \%)$ yang mengalami lilitan tali pusat, yang tidak ada kelainan sebanyak 206 responden $(68,7 \%)$.

\section{Analisis Bivariat}

Analisis bivariat dalam penelitian ini adalah analisis secara stimultan dari dua variabel, yaitu untuk mengetahui hubungan bayiberat lahir rendah (BBLR) dengan kejadian asfiksia neonatorum di Rumah Sakit Dr. H. Abdul Moeloek Bandar Lampung Tahun 2016. 


\section{Hubungan Bayi Berat Lahir Rendah (BBLR) Dengan Kejadian Asfiksia Neonatorum}

Tabel 12.

Hubungan bayi berat lahir rendah (BBLR) dengan kejadian asfiksia neonatorum di Rumah Sakit Dr. H. Abdul Moeloek Bandar Lampung Tahun 2016

\begin{tabular}{|c|c|c|c|c|c|c|c|c|}
\hline \multirow{3}{*}{ BBLR } & \multicolumn{4}{|c|}{ Asfiksia Neonatorum } & \multirow{3}{*}{ TOTAL } & \multirow{3}{*}{$N(\%)$} & \multirow{3}{*}{ P VALUE } & \multirow{3}{*}{$\begin{array}{c}\text { OR } 95 \% \\
\text { Confidence Interval }\end{array}$} \\
\hline & \multicolumn{2}{|c|}{ Asfiksia } & \multicolumn{2}{|c|}{$\begin{array}{c}\text { Tidak } \\
\text { Asfiksia }\end{array}$} & & & & \\
\hline & $\mathrm{N}$ & $\%$ & $\mathrm{~N}$ & $\%$ & & & & \\
\hline BBLR & 97 & 62,2 & 26 & 18,1 & 123 & 41 & 000 & 7,526 \\
\hline TIDAK BBLR & 59 & 37,8 & 118 & 81,9 & 177 & 59 & 0,000 & $(4,438-12,763)$ \\
\hline JUMLAH & 156 & 100 & 144 & 100 & 300 & 100 & & \\
\hline
\end{tabular}

Berdasarkan tabel 12 diketahui bahwa BBLR yang mengalami asfiksia yaitu sebanyak 97 responden $(62,2 \%)$, sedangkan bayi BBLR yang tidak mengalami asfiksia yaitu sebanyak 26 responden (18,1\%). Kemudian bayi yang tidak BBLR (Dismatur) yang mengalami asfiksia sebanyak 59 responden $(37,8 \%)$, sedangkan bayi yang tidak BBLR (Dismatur) dan tidak mengalami asfiksia sebanyak 118 responden $(81,9 \%)$.

Hasil uji statistik yang dilakukan menggunakan chi square didapatkan nilai $p$-value $=$ 0,00 hal ini berarti bahwa ada hubungan bayi berat lahir rendah dengan kejadian asfiksia neonatorum di Rumah Sakit Dr. H. Abdul Moeloek Bandar Lampung. Kemudian didapatkan nilai $\mathrm{OR}=7,526$, hal ini berarti bahwa bayi BBLR mempunyai risiko mengalami asfiksia sebanyak 7,526 kali dibanding dengan bayi yang tidak mengalami BBLR.

\section{PEMBAHASAN}

Distribusi Frekuensi Bayi Berat Lahir Rendah

Berdasarkan tabel 1 diketahui bahwa dari 300 sampel didapatkan 123 sampel $(41,0 \%)$ yang mengalami bayi berat lahir rendah dan 177 sampel $(59,0 \%)$ yang tidak bayi berat lahir rendah. Hal ini menunjukkan bayi yang di rawat di ruang Perinatologi Rumah Sakit Dr. H. Abdul Moeloek terbanyak yaitu tidak BBLR.

\section{Distribusi frekuensi asfiksia neonatorum}

Berdasarkan tabel 2 diketahui bahwa kejadian asfiksia neonatorum yaitu asfiksia sedang 140 sampel $(47,0 \%)$ dan tidak asfiksia sebanyak 121 sampel $(40,0 \%)$, sedangkan asfiksia berat sebanyak 39 sampel $(13,0 \%)$. Dari data tersebut dapat diketahui bahwa frekuensi terbanyak yang mengalami asfiksia di ruang Perinatologi Rumah Sakit Dr. H. Abdul Moeloek adalah asfiksia sedang. Hal ini terjadi karena beberapa faktor risiko yang mempengaruhi kejadian asfiksia neonatorum yaitu, ketuban pecah dini, preeklampsi berat, kehamilan ganda.

\section{Distribusi frekuensi faktor ibu}

Berdasarkan tabel 3 diketahui ibu yang mengalami ketuban pecah dini yaitu sebanyak 155 responden $(51,7 \%)$. Data tersebut menunjukkan bahwa ruang Perinatologi di Rumah Sakit Dr. H. Abdul Moeloek sebagian besar bayi berat lahir rendah disebabkan karena faktor ibu, yaitu ibu yang mengalami ketuban pecah dini. Berdasarkan tabel 4 diketahui ibu yang mengalami solusio plasenta adalah 72 responden $(24,0 \%)$. Hal ini menunjukkan bahwa ruang Perinatologi di Rumah Sakit Dr. H. Abdul Moeloek dari faktor ibu yang menyebabkan bayi berat lahir rendah yaitu solusio plasenta tidak terlalu mempengaruhi kejadian bayi berat lahir rendah.

Berdasarkan tabel 5 dapat diketahui ibu yang mengalami plasenta previa yaitu sebanyak 46 responden $(15,3)$. Dari data tersebut dapat diketahui bahwa ruang Perinatologi di rumah sakit Dr. H. Abdul Moeloek dari faktor ibu yang menyebabkan bayi berat lahir rendah yaitu plasenta previa hanya sebagian kecil mempengaruhi kejaddian bayi berat lahir rendah.

Berdasarkan tabel 6 dapat diketahui bahwa kejadian bayi berat lahir rendah ruang Perinatologi di Rumah Sakit Dr. H. Abdul Moeloek dipengaruhi karena faktor ibu yang mengalami eklampsi yaitu sebanyak 96 responden $(32,0 \%)$, kemudian kelompok terkecil yang mempengaruhi kejadian bayi berat lahir rendah yaitu preeklampsi berat sebanyak 37 responden (12,3\%).

\section{Distribusi frekuensi faktor janin}

Berdasarkan tabel 7 diketahui bahwa faktor yang menyebabkan bayi berat lahir rendah dilihat dari faktor janin yaitu sebanyak 177 responden $(59,0 \%)$ bayi yang mengalami dismatur. Hal ini menunjukkan bahwa bayi berat lahir rendah di ruang Perinatologi di Rumah Sakit Dr. H. Abdul Moeloek sebagian besar adalah dismatur.

Dari tabel 8 diketahui bahwa faktor yang 
menyebabkan bayi berat lahir rendah yaitu hidramnion dimana frekuensinya yaitu sebanyak 20 responden (6,7\%). Berdasarkan data tersebut diketahui bahwa sebagian kecil kejadian hidramnion tidak terlalu mempengaruhi kejadian bayi berat lahir rendah di ruang Perinatologi di Rumah Sakit Dr. H. Abdul Moeloek.

Berdasarkan tabel 9 dapat diketahui bahwa faktor yang menyebabkan bayi berat lahir rendah yaitu kehamilan ganda sebanyak 24 responden $(8,0 \%)$. Hal ini menunjukkan bahwa dari faktor janin yaitu kehamilan ganda termasuk dalam kelompok kecil yang menyebabkan bayi berat lahir rendah di Ruang Perinatologi di Rumah Sakit Dr. H. Abdul Moeloek.

\section{Distribusi frekuensi faktor persalinan}

Berdasarkan tabel 10 dapat diketahui bahwa faktor yang dapat menyebabkan bayi berat lahir rendah yaitu oligohidramnion sebanyak 102 responden (34,0\%). Hal ini berarti bahwa kelompok tersebut tidak terlalu mempengaruhi terjadinya bayi berat lahir rendah di Ruang Perinatologi di Rumah Sakit Dr. H. Abdul Moeloek.

Dari tabel 11 dapat diketahui bahwa faktor yang dapat menyebabkan bayi berat lahir rendah yaitu lilitan tali pusat yaitu sebanyak 94 responden $(31,3 \%)$. Halini menunjukkan bahwa kelompok tersebut cukup mempengaruhi terjadinya bayi berat lahir rendah di Ruang Perinatologi di Rumah Sakit Dr. H. Abdul Moeloek.

\section{Hubungan bayi berat lahir rendah dengan kejadian asfiksia neonatorum}

Bayi berat lahir rendah adalah bayi dengan berat lahir $<2500$ gram. Bayi berat lahir rendah dapat terjadi pada bayi premature ataupun dismature. Kejadian bayi berat lahir rendah masih menjadi masalah karena masih cukup tinggi di Indonesia.Asfiksia neonatorum adalah keadaan bayi baru lahir yang gagal bernapas secara spontan dan teratur segera setelah lahir. Asfiksia neonatorum ini biasanya disertai dengan adanya hipotonus, hiperkapnea, dan berakhir dengan asidosis, apabila penanganan terlambat maka pada 24 jam sampai 72 jam kemudian dapat menyebabkan perburukan seperti koma, apnea lama, dan mati batang otak. Penyebab asfiksia neonatorum anatara lain dari faktor ibu (pre eklampsi), faktor janin (prematuritas), faktor persalinan (solusio plasenta) (Abdoerrachman dkk, 1985; Manoe \& Amir, 2003).

Berdasarkan penelitian yang dilakukan di Rumah Sakit Dr. H. Abdul Moeloek Bandar Lampung di ruangan perinatologi dan mengambil data rekam medik tahun 2016 didapatkan hasil bahwa bayi BBLR yang mengalami asfiksia sebanyak 97 responden $(62,2 \%)$, sedangkan bayi BBLR (Dismatur) yang tidak mengalami asfiksia yaitu sebanyak 26 responden (18,1\%). Kemudian bayi yang tidak BBLR yang mengalami asfiksia sebanyak 59 responden $(37,8 \%)$, sedangkan bayi yang tidak BBLR (dismatur) yang tidak mengalami asfiksia sebanyak 118 responden $(81,9 \%)$. Nilai OR dalam penelitian ini adalah 7,526 dengan tingkat kepercayaan sebesar $95 \%$ hal ini berarti bahwa bayi dengan BBLR memiliki risiko terjadi asfiksia 8 kali lipat dibandingkan dengan bayi berat lahir cukup. Hasil uji statistik menggunakan chi square diperoleh nilai $p$-value $=0,000$ hal ini berarti ada hubungan bayi berat lahir rendah dengan kejadian asfiksia neonatorum di Rumah Sakit Dr. H. Abdul Moeloek Bandar Lampung.

Penelitian ini sejalan dengan penelitian yang telah dilakukan oleh Saputro dkk (2015) di Surakarta menggunakan uji statistik chi square dengan populasi dalam penelitian sebanyak 127 bayi dan jumlah sampel yang diambil sebanyak 98 orang pada tahun 2015. Peneltian ini didapatkan hasil yaitu ada hubungan yang bermakna antara berat badan lahir rendah dengan asfiksia neonatorum dengan berat badan lahir cukup (BBLC) sebanyak $60,5 \%$, sedangkan sebagian kecil merupakan bayi tidak asfiksia dan berat badan lahir rendah (BBLR) yaitu sebanyak $6,1 \%$ dengan nilai $p$ value $=0,000$. Maka dilihat dari hasil penelitian yang telah dilakukan bahwa ada hubungan bayi berat lahir rendah dengan kejadian asfiksia neonatorum.

Penelitian inipun sejalan dengan peneitian yang telah dilakukan oleh Binilang (2013) di RSUD Mala Kabupaten Talaud dengan sampel sebanyak 70 bayi. Hasil dari penelitian ini yaitu sebagian besar bayi mengalami asfiksia neonatorum $(71,4 \%)$, sebagian kecil tidak mengalami asfiksia neonatorum $(28,6 \%)$. Berdasarkan hasil uji statistik chi square diperoleh nilai $p$-value $=0,017$ sehingga kesimpulan dari penelitian ini ada hubungan bayi BBLR dengan kejadian asfiksia neonatorum.

Namun penelitian ini tidak sejalan dengan penelitian yang telah dilakukan oleh Fajarwati (2016) di Semarang menggunakan uji statistik chi square dengan sampel sebanyak 334 kasus. Penelitian ini didapatkan hasil yaitu berat badan lahir berisiko sebesar $17,4 \%$ dan berat badan tidak berisiko sebesar 82,6\%. Kejadian asfiksia neonatorum sebesar $26,3 \%$ dan tidak asfiksia sebesar $73,7 \%$, dengan nilai $p$-value $=0,674$ sehingga dapat disimpulkan bahwa tidak terdapat hubungan yang bermakna antara berat badan lahir dan asfiksia neonatorum.

Berdasarkan uraian diatas dapat ditarik 
kesimpulan bahwa $\mathrm{HO}$ ditolak dan $\mathrm{Ha}$ diterima, yang artinya terdapat hubungan bayi berat lahir rendah dengan kejadian asfiksia neonatorum.

\section{KESIMPULAN}

Berdasarkan hasil penelitian hubungan bayi berat lahir rendah dengan kejadian asfiksia neonatorum di Rumah Sakit Dr. H. Abdul Moeloek Bandar Lampung Tahun 2016 didapatkan kesimpulan sebagai berikut: Jumlah Bayi Berat Lahir Rendah di Rumah Sakit Dr. H. Abdul Moeloek Bandar Lampung tahun 2016 sebanyak 123 responden $(41,0 \%)$ dan bayi tidak BBLR (Dismatur) sebanyak 177 responden $(59,0 \%)$, Jumlah bayi yang mengalami asfiksia berat yaitu sebanyak 39 responden (13,0\%), asfiksia sedang sebanyak 140 responden $(47,0 \%)$, tidak asfiksia sebanyak 121 responden (40,0\%),Jumlah bayi berat lahir rendah yang mengalami asfiksia sebanyak 97 responden $(62,2 \%)$, sedangkan bayi berat lahir rendah yang tidak mengalami asfiksia sebanyak 26 responden (18,1\%). Kemudian bayi yang tidak BBLR (Dismatur) yang mengalami asfiksia sebanyak 59 responden $(37,8 \%)$, dan bayi yang tidak BBLR (Dismatur) yang tidak mengalami asfiksia sebanyak 118 responden (81,9\%),Faktor-faktor yang menyebabkan bayi berat lahir rendah di Rumah Sakit Dr. H. Abdul Moeloek Bandar Lampung dengan frekuensi tertinggi dari faktor ibu yaitu ketuban pecah dini sebanyak 155 responden $(51,7 \%)$, dan frekuensi terendah dari faktor janin yaitu hidramnion sebanyak 20 responden $(6,7 \%)$,Ada hubungan bayi berat lahir rendah dengan kejadian asfiksia neonatorum di Rumah Sakit Dr. H. Abdul Moeloek Bandar Lampung tahun 2016 dengan nilai $p$-value $=0,000$ dan nilai OR 7,526 dengan tingkat kepercayaan $95 \%$ yang artinya bayi BBLR memiliki risiko terjadi asfiksia 8 kali lipat dibanding dengan bayi tidak BBLR (Dismatur).

\section{SARAN}

Bagi institusi Institusi pendidikan diharapkan dapat menghasilkan lulusan tenaga kesehatan yang kompeten dalam menangani bayi berat lahir rendah dan asfiksia untuk mencegah keadaan yang tidak diharapkan.Bagi peneliti selanjutnya diharapkan adanya penelitian lebih lanjut untuk mencari faktor risiko lain yang dapat mengakibatkan BBLR Bagi tempat penelitian
(RSUAM) dapat digunakan untuk meningkatkan kualitas penanganan bayi berat lahir rendah dan asfiksiaBagi masyarakat diharapkan dari penelitian ini dapat dijadikan informasi mengenai hubungan bayi berat lahir rendah dengan kejadian asfiksia neonatorum dan agar dapat mengurangi faktor risiko terjadinya BBLR.

\section{DAFTAR PUSTAKA}

Abdoerrachman, M., M.B, A., \& S, A. (1985). IImu Kesehatan Anak. Jakarta: Universitas Indonesia. HIm 10511053, 1072, 1073, 1077-1079.

Binilang, E., Madianung, A., dan Masi, G. (2013). Hubungan Bayi Berat Badan Lahir Rendah dengan Kejadian

Asfiksia Neonatorum di RSUD Mala Kabupaten Talaud. E-Ners, 1 (1).

Dewi, N., Setyowireni,D.,\& Surjono, A. (2005). Faktor Risiko Asfiksia Neonatorum Pada Bayi Cukup Bulan. Berkala IImu Kedokteran, 37 (3), 144.

Dinkes. (2014). Profil Kesehatan Kota Bandar Lampung.

Fajarwati, N., Andayani, P., \& Rosida, L. (2016). Hubungan Antara Berat Badan Lahir Dan Kejadian Asfiksia Neonatorum. Berkala Kedokteran, 33-39.

Herawati, R. (2013). Faktor-Faktor yang Menyebabkan Terjadinya Asfiksia Neonatorum Pada Bayi Baru Lahir Di

Rumah Sakit Umum Daerah Kabupaten Rokan Hulu. Maternity and Neonatal , 2 (2), $75-85$

Kemenkes RI. (2014). Kesehatan Keluarga.Kementerian Kesehatan Republik Indonesia Tahun 2015.

Manoe, V. M., \& Amir, I. (2013). Gangguan Multi Fungsi Organ pada Bayi Asfiksia Berat. Sari Pediatri , 5 (2), 7278.

Prawirohardjo, S. (2009). Buku Acuan Nasional Pelayanan Kesehatan Maternal Dan Neonatal. Jakarta: PT Bina Pustaka. HIm 347.

Saputro, S. D. (2015). Hubungan Antara Berat Badan Lahir Rendah Dengan Asfiksia Neonatorum. [Skripsi].

Surakarta: Universitas Muhammadiyah Surakarta.

Suyoko, E. D., Siregar, S. P., \& Sumadino. (2010). Pedoman Pelayanan Medis. Jakarta: Ikatan Dokter Anak Indonesia. HIm 23. 